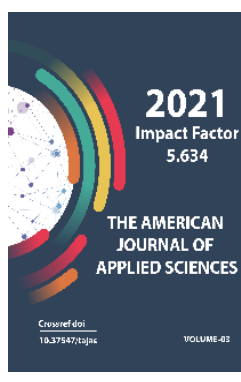

Journal Website: http://usajournalshub.c om/index,php/tajas

Copyright: Original content from this work may be used under the terms of the creative commons attributes 4.0 licence.

\section{Methodological Basis Of Creation, Organization And Decoration Of Platter's Artistic Composition In Applied Art}

\author{
Rasulov Murad Absamatovich \\ Senior Lecturer Of The Department Of Fine Arts, Tashkent State Pedagogical University \\ Named After Nizami, Uzbekistan
}

Abdurashidkhonova Muslimahon Bahodirhon Kizi

Student Of The Ts-202 Group Of The Educational Direction Fine Arts And Engineering Graphics, Tashkent State Pedagogical University Named After Nizami, Uzbekistan

\title{
ABSTRACT
}

The article contains all the patterns that have been used since ancient times in Applied Arts, although they are conditional representations of nature and reality, they have their own rules, and these rules are derived in a stylized way from nature itself. The article provides information on the artistic processing of the bowl, which is typical of the art of woodcarving.

\section{KEYWORDS}

Pattern, ruler, pargor, kalka, islimi, composition, chakich, sandpaper, pax, choka, lula, layer, sherlak, relief, dissertation.

\section{INTRODUCTION}

Plate processing in woodcarving requires special attention and great skill from the master. This is because the surface of the tray will not be as flat as usual, but will be bent inwards, i.e. the inside of the tray will be somewhat deepened, like the ordinary trays we know. That is why it is a little difficult to carve a pattern for him. However, the bowl is a wonderful piece of woodcarving, which can be carved from pattern compositions in several ways. For example:

- Self-engraving of Islamic pattern composition; 
- Mixing Islamic pattern composition and pargora pattern composition;

- Carving only pargora pattern composition;

- Processing by collaborating with carving and painting.

The method we learn is a method that involves both carving and painting. Since the method developed in the painting does not correspond to the theme, we can distinguish only the part pertaining to carving. The bowl is divided into two parts, the middle part is engraved with a pattern, and the outer part is engraved with a pattern of woodcarving [1-6].

Before creating a pattern composition on a tray, it is necessary for accurately measure the size of the piece, which is important for the quality and more attractive appearance of the piece. Various tools are used to measure the size of the item. For example, a ruler, pargor (compass) and a number of other tools will be needed [7-11]. Once the size of the item is accurately measured, we need to think about what kind of pattern composition will be created for the item, imagining that the item will look more elegant, beautiful and attractive.It depends on the composer's worldview, the breadth of his thinking, and most importantly, his subtle nature and high level of taste. This means that when you come to a stop, a pattern composition is drawn on the paper. Before creating a composition, it is advisable to clarify something, that is, it is especially important to consider what material the item is made of. Larger types can be used if they are made of soft material and smaller and more complex patterns if they are made of hard material.
There are all the patterns that Uzbek folk masters have been using since ancient times, and they have their own rules, despite the fact that they are conditional images of nature and reality. These rules are derived in a stylized way from nature itself. Usually plants grow in one direction, which is a law of nature. In the example of the willow, for example, the willow may seem to be growing downwards, but in reality, it grows from the root to the body, from the body to the branch, from the branch to the leaf [12-18]. This law of nature is also reflected in the pattern.Pattern compositions drawn by a master painter do not mean simply filling a sheet of paper or engraving a carved face, but drawing a pattern composition consciously following the laws of nature and art. From this point of view, the most difficult and responsible stage in the creative process of a sculptor is to draw a copy of the pattern composition.If the composition of the pattern is made contrary to the laws of nature, then no matter how much success is achieved in carving and decorating, the work will not be as beautiful and attractive as it should be. In general, the carved pattern looks very beautiful, beautiful and attractive, but after a while the mistakes and shortcomings in the composition of the pattern, the flaws become apparent.

To draw a composition on a platter, it is divided into 6 parts using a compass. Draw a few of the compositions of the pattern according to the size taken from the item. The most suitable is selected from the compositions of the drawn pattern. Usually the composition of the structured pattern is made of kalka (china pattern copied on Chinese paper or transparent paper). But we are acting out of the ordinary. That is, we can reproduce the composition of the finished pattern in the most 
common copiers today (photocopies).The advantage of this method is that it takes more time if the composition is applied to the wood using a sledgehammer, but the new method allows us to save time. Today, most wood carvers use the technique of copying on modern machines and then gluing the copy to wood [19-22].

A copy of the duplicated pattern is cut to the desired size using scissors and placed on the tray to the exact locations marked, and glued in plain paper glue.

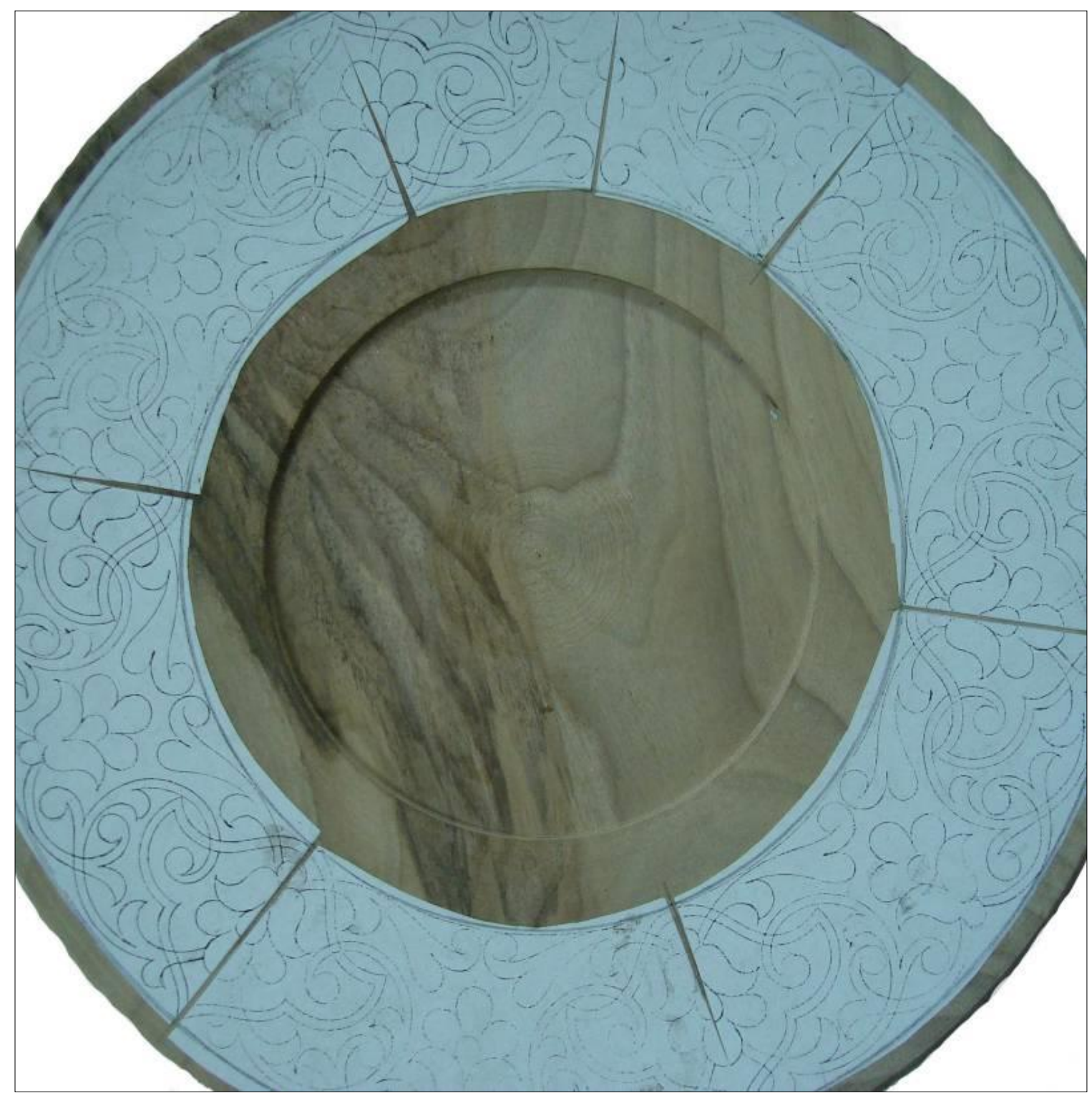

A view of the paper of the drawn pattern affixed to the platter

Once the pattern is lowered into the tray, it is cut on the lines with the necessary tools. If we look closely at these tools, we can see how they are cut by hammering the bottom of each tool, and each one is marked with a serial number. When we cut a pattern, we always find the smallest circle line, the work begins by cutting that circle first and grows according to 
the order number of the tools, and finally when

it comes to the tool that cuts the straight line, all the lines of the pattern are cut.

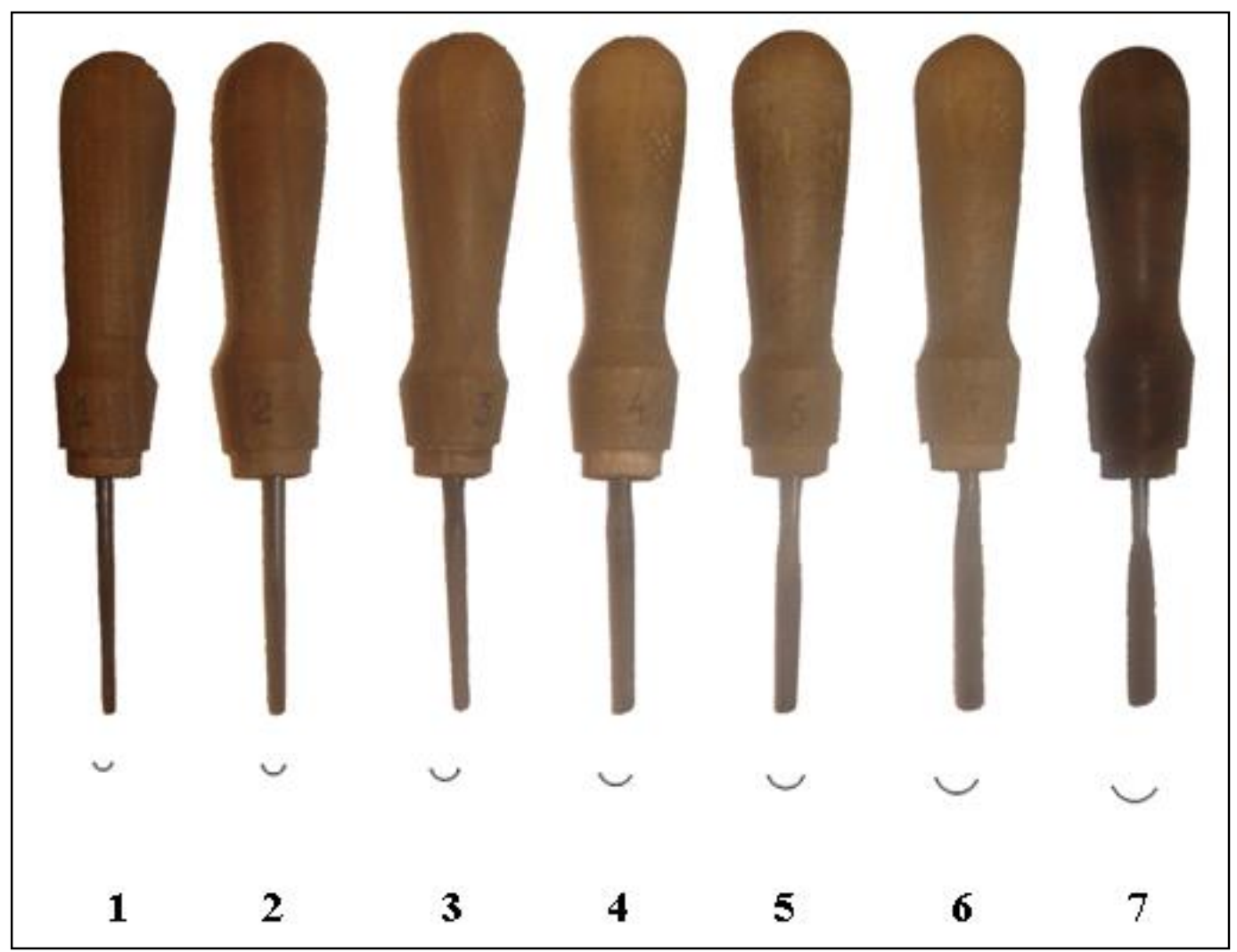




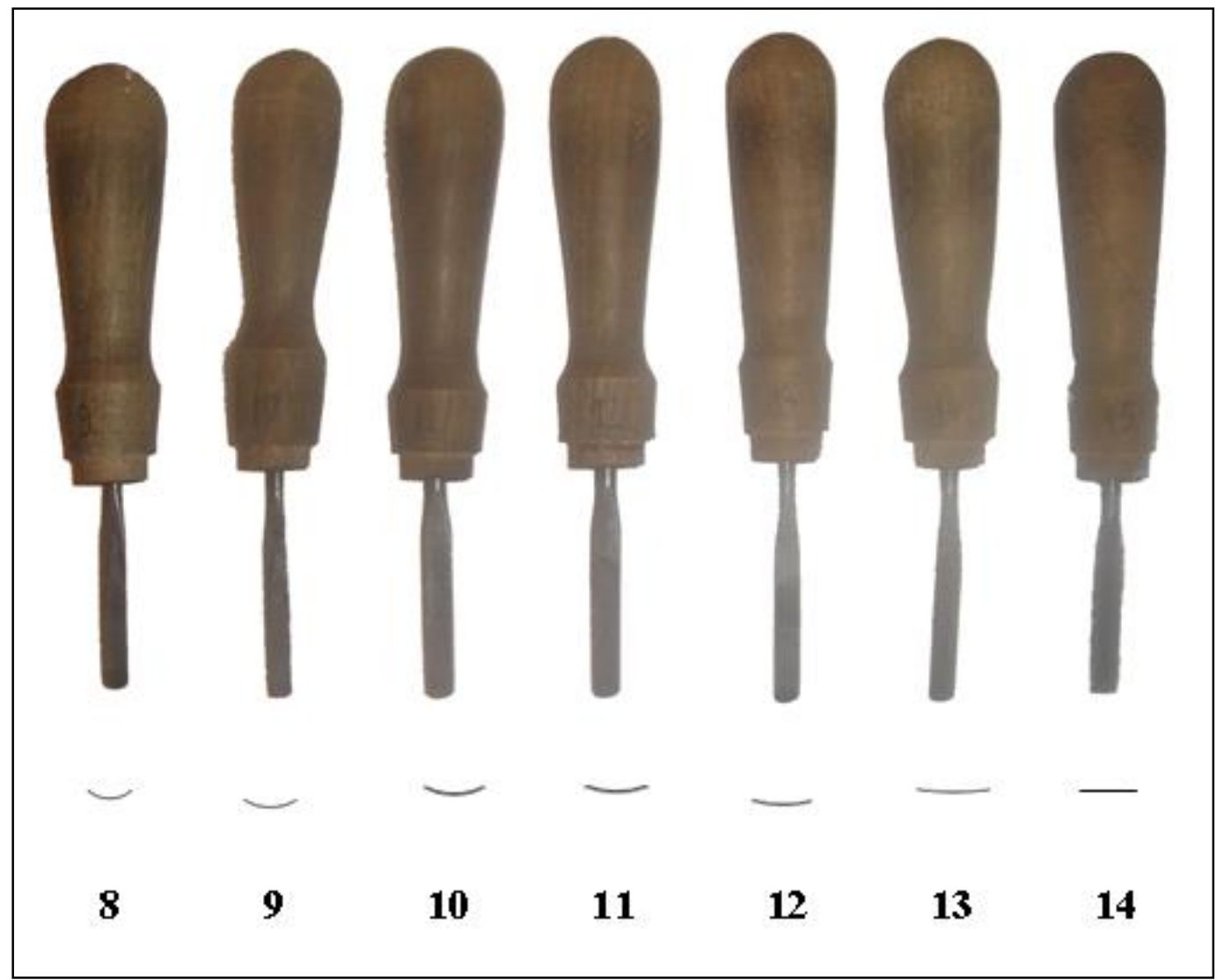

An overview of the tools used for cutting in woodcarving 


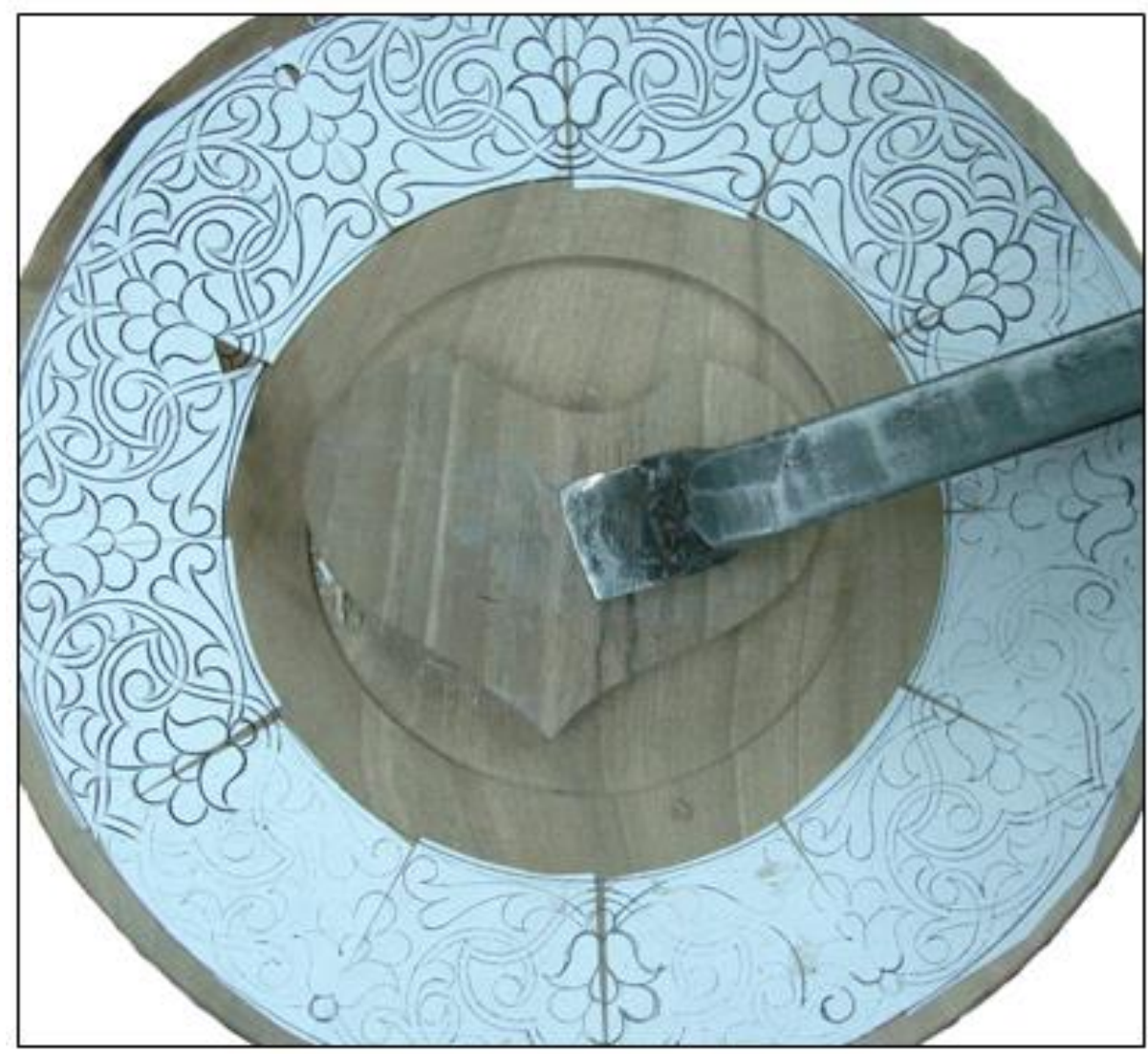

The cutout view over the lines of the pattern composition drawn on the tray with the above tools

The tools are in the above position and sharpened to one side. Tools should be chosen to be very thin, medium and thick depending on where you are carving.

When laying the "zamin" pay attention to the following:
- When cutting, lower each cutting tool to its proper position;

- Rightly and smooth carving;

- Do not blow branches;

- Be careful when handling and pay attention to all similar rules. 

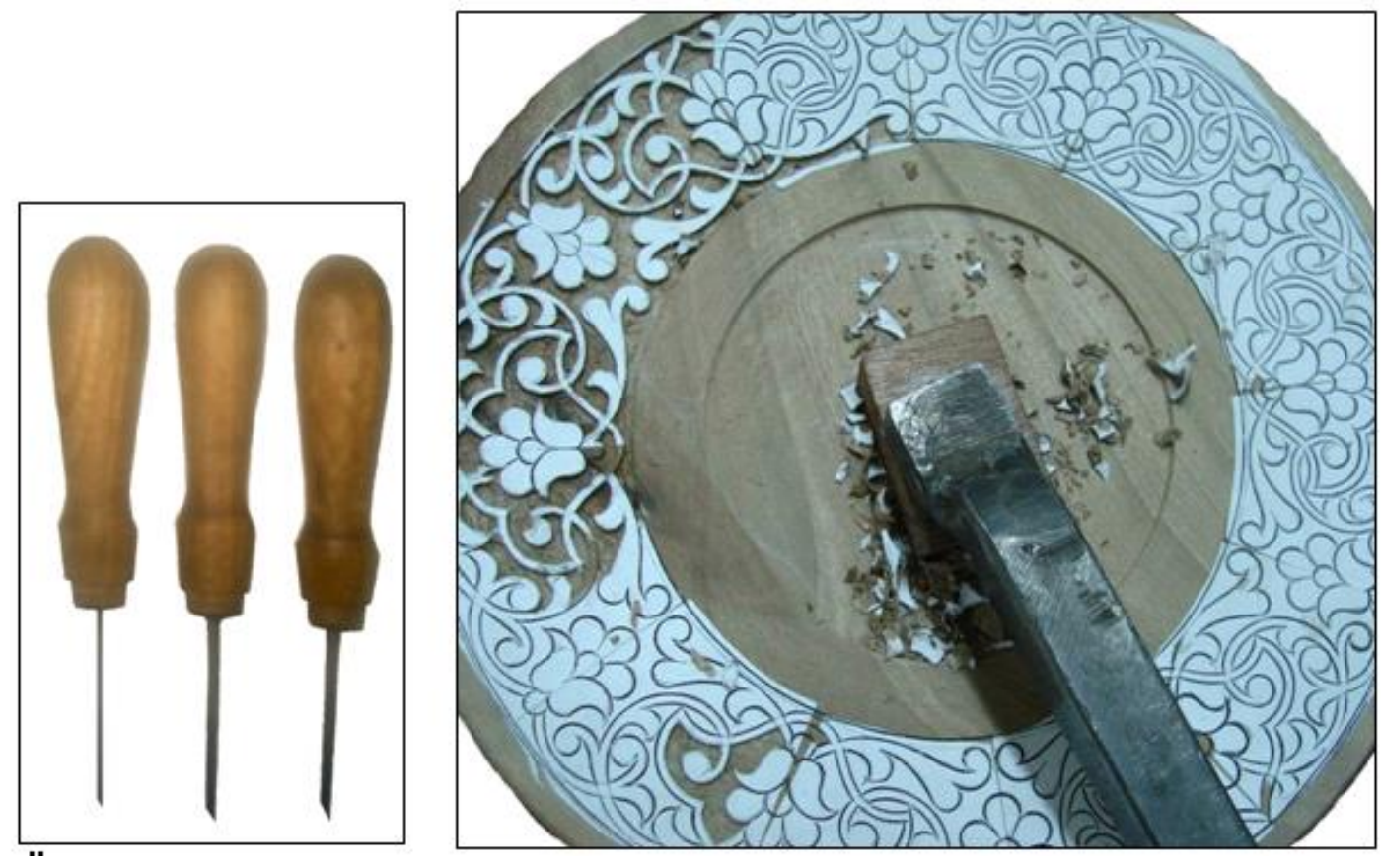

Carving toolsthe appearance of the platter at the time of carving

The next stage is the stage of printing patterns and flowers on the carved "zamin", in which a drawing pen, i.e. a carving tool, is selected large or small, depending on the pattern composition. Carving itself is an art. The patterned "zamin", which is beautifully drawn on a flat surface and in moderation, gives the item a special beauty.
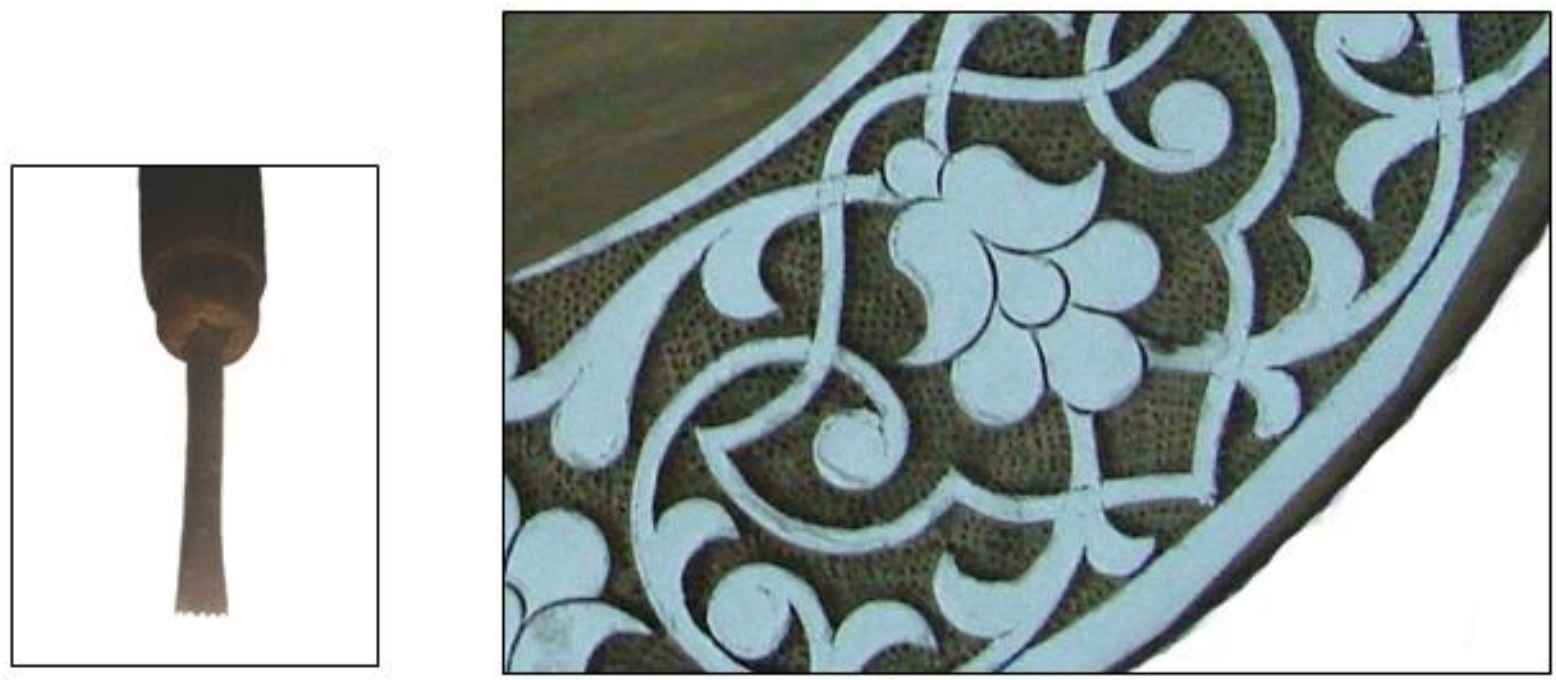

Pattern drawing tool the embroidered appearance of the "zamin" of the carved pattern 
After placing the pattern on the tray, cut, engraved and chopped, it is thoroughly polished with sandpaper.First rubbed with larger, medium and finally small sandpaper.It is not necessary to leave any of the glued papers, after the surface of the product is leveled, the sandpaper work is completed.

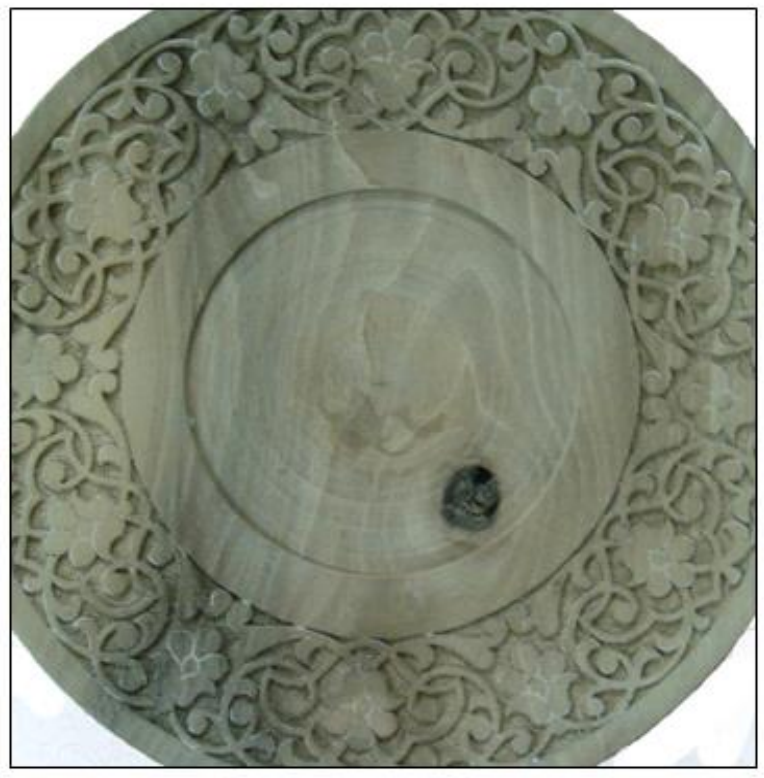

Since there is some space left between the middle part of the tray and the carved pattern composition, there is a very small form of the return pattern. Once all of the above is done, it is the turn of the pattern lacquering stage. Lacquering comes in two different ways:

The appearance of polishing with sandpaper

1. Lacquering in ordinary colorless oil varnish;

2. Lacquering with a tampon on the sherlak.
We work using the second method. To do this, firstly lubricate the surface of the tray with machine oil, then after a few hours the oil dries, rub the surface with a very fine sandpaper. Stains left by the varnish are wiped off.Sherlak is prepared by dissolving it in alcohol, so its main ingredient is alcohol. This is why it cannot be given directly to the wood with a brush. To give the bowl a glaze, a simple cotton ball is rounded, wrapped in a piece of cotton cloth and gently moistened with the glaze, rubbed into the smooth surface of the platter without dipping evenly. This process is continued until the cotton wrapped in the fabric dries and is allowed to rest for a few minutes, after which it is again given sherlak. The product is applied at least three times and the work of lacquering is completed.

After the lacquering work is done, of course, finally finishing work of decoration is done.At the end of the process, the product is being processed, polished and flattenedin wood carving as types of folk arts, for example jewelry, made work of "ganch", coppersmith and pottery.For example, in wood carving, there are a total of 6 types of makeupin wood carving which are divided into cut, drawing, cotton, choke, tulip and layer makeup. Of these, four types, namely pax, choka, lulaand layer makeup, are used to decorate the relief. The types of this makeup are divided into 2: simple (pax and choka) and complex (lula and layer) makeup types.

Typically, the type of makeup is chosen according to the nature of the structured pattern composition. When choosing the type of makeup should not forget to take into account both light and shadow. For example: 
Pax makeup is a simple type of makeup that is carved in wood carving with the relief of the carved pattern cut to one side. We can call this makeup a spread makeup. Masters believe that pax makeup was created as a result of carving a "zanjira".Pax makeup is much easier than choka makeup, turquoise makeup and layer makeup, the light and shadow given in the cotton makeup will have a much softer and softer look.

Choka makeup is a type of makeup in which the slope of the band of the pattern is revealed and cut lengthwise. This makeup is also called cereal makeup. The masters of the Kokand school of wood carving make extensive use of this type of decoration. Choka makeup requires skill and talent from the sculptor. The pattern decorated with this type of makeup acquires a unique charm.

Lula makeup is a type of intricate makeup that is carved into a semi-circular look. This type of makeup is widely used not only in wood carving, but also in plaster and stone carving. Lula makeup is the latest type of makeup to be used. If the carving is decorated with tulip makeup, the depth of the carving will be reduced and the pattern will have a delicate look.

Layer make-up is a type of make-up created by Bukhara masters in the XIX century, in which the leaves and flowers are carved in two or three layers. Layer makeup is the most sophisticated of all types of makeup, which requires professional skill from the makeup artist.

It is not possible to use tulip makeup because the surface of the tray being worked is carved. Therefore, layer makeup is used in makeup.

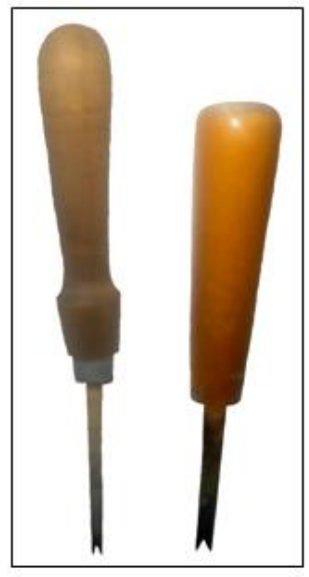

Opening device

for line

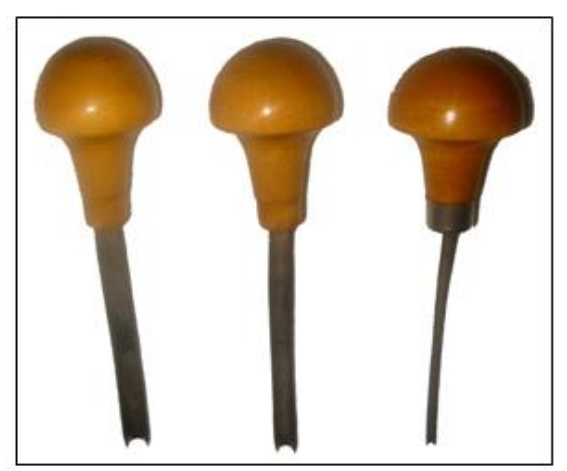

grinding tools

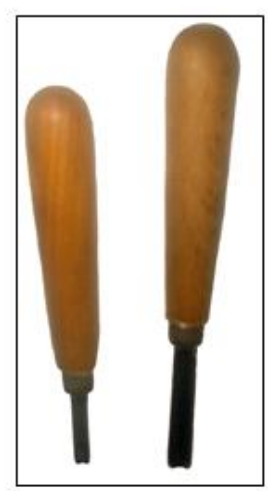

opening device for round deep 
Masters will need a few makeup tools to decorate the items. Makeup tools are divided into several types in terms of the functions they perform. For example: tools used to open a line, a chisel, and a hole in a round shape. Cutting and carving tools are also used in some places during the decorating process.At the stage of decorating the platter, the work begins with the tools previously used for finishing and opening the line. In this process, holding the tool in the left hand, the hammer in the right hand, gently tapping, revealing the middle of the branches, the edges of the flowers and leaves.Then, using special tools that open the groove in a round shape, the "margulas" and the necessary parts are opened again. Once this is done, the peeled parts of the flowers and leaves are scraped and bleached using special tools that are scraped off [23-25].

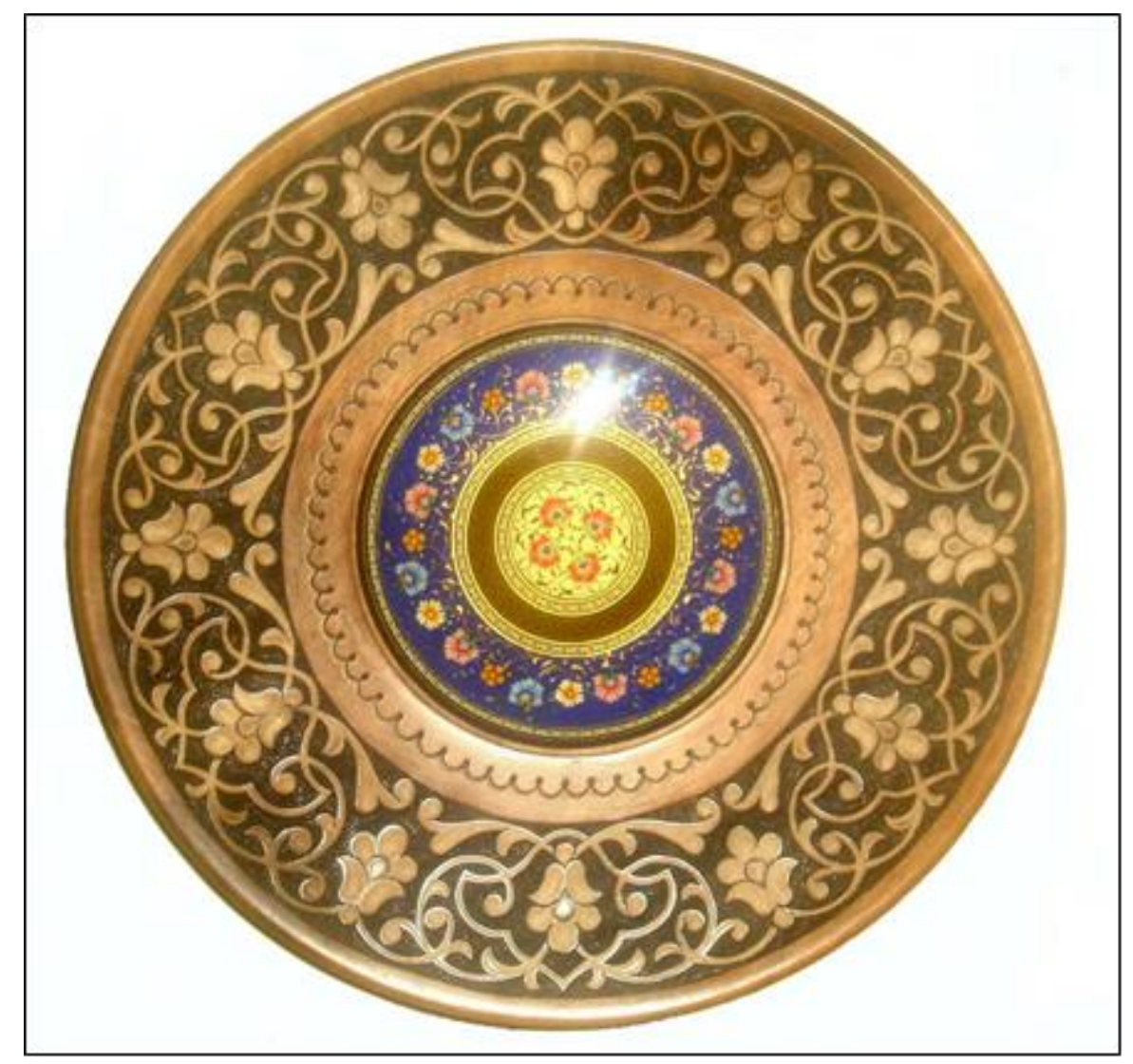

\section{The finished state of the tray}

\section{CONCLUSION}

One of the most pressing issues today is the methodologically correct organization and conduct of woodcarving classes for young people in higher education, the development 
of methodological bases, and the importance of teaching our national art to the next generation.I chose the topic of my dissertation as the subject of scientific and methodological bases of teaching wood carving in higher education institutions. To do this, I analyzed the methodology of processing the items. I directly visited the wood carving workshops and watched the creative work of the mature masters of our country. I then chose the above forms in order to reflect my nationality in my dissertation.

I also tried to perform the following tasks in the implementation of the dissertation:

- Information on the history of wood carving in Uzbekistan;

- To get acquainted with the schools of wood carving in Uzbekistan, creative masters and their life activities, to study their creative methods;

- Study the basic laws of composition in wood carving;

- Analysis of the methodological basis of creating, carving and decorating a pattern composition on a plate.

In carrying out my dissertation, I analyzed the wood carving lessons of higher education institutions.I studied the state standards of applied arts education in higher education institutions and tried to determine the current state of teaching woodworking in wood carving classes.

\section{REFERENCES}

1. “Халқ бадиий хунармандчилик ва амалий санъатни янада ривожлантиришни давлат йўли билан қўллаб-қувватлаш чора тадбирлари тўғрисида". Ўзбекистон
Республикаси Президентининг фармони Т., “Тошкент оқшоми” 2 апрел 1997.

2. Булатов С.С. "Ўзбек халқ амалий безак санъати". - Т., Мехнат, 1991.

3. Ниғмонов Б. "Нақш композицияларини тузиш”. - Т., “Низомий номидаги ТДПУ”, 2006.

4. Ахмедов М.Б. "Ёғоч ўймакорлиги". - Т., “Низомий номидаги ТАПУ”, 2002.

5. A'zamjon Valiyev, Khayriddin Amirqulov and Sevinch Abdumutalibova. Heuristic Teaching Technology and Its Practical Application Which in Teaching of Draftsmanship.International Journal of Progressive Sciences and Technologies (DPSAT). ISSN: 2509-0119. 2019 International Journals of Sciences and High Technologies. Vol. 17 No. 1 October 2019, pp. 281-284. https://ijpsat.ijshtjournals.org/index.php/ijpsat/article/view/13 08

6. Jabbarov Rustam Ravshanovich. (2021) PRIORITIES FOR THE DEVELOPMENT OF PAINTING. Конференции, 1(1). SECTION 1, pp-39-49,

https://doi.org/10.47100/conferences.v111.9 52

7. Tashimov Nurlan, Samandar Zaitov. (2021) Improving the quality and efficiency of teaching descriptive geometry in a creditmodular

system.ACADEMICIA:ANINTERNATIONAL MULTIDISCIPLINARY RESEARCH JOURNAL.ume:11, Issue:2, pp-730-733. DOI : 10.5958/2249-7137.2021.00398.0

8. Muratov Xusan Xolmuratovich, Jabbarov Rustam Ravshanovich AMALIY va BADIIY bezak san'ati. UO'K 76(075); KBK85.15; M88 ISBN 978-9943-6383-4-1. 2020 yil. http://lib.cspi.uz/test/Amaliy\%20san'at/mobi le/index.html\#p=1 
The American Journal of Applied sciences

(ISSN - 2689-0992)

Published: April 30, 2021 | Pages: 298-310

9. Мансуров Н.А., Жалилова В.С. Методика профессионального обучения - научная отрасль профессиональной педагогики. https://doi.org/10.36074/scientia-26.03.2021 March 26,2021, Chicago, USA, Collection of scientific papers «SCIENTIA» pp-144-145, Sectoral research XXI: characteristics and features Volume https://ojs.ukrlogos.in.ua/index.php/scienti a/issue/view/26.03.2021/487

10. Akhmedov

Mukhamod-Umar

Bakhridinovich, KholmatovaFeruzakhon Muhammad Umar qizi. Formation of creative processes in students through teaching composition in fine arts.«MULTIDISZIPLINÄRE FORSCHUNG: PERSPEKTIVEN, PROBLEME UND MUSTER» 9. APRIL 2021 - WIEN, REPUBLIK ÖSTERREICH, DOI $10.36074 /$ logos09.04.2021.v2.03

11. Расулов Мурад Абсаматович. Научить студентов вовне школьных учереждениях составлять композициина уроках резьбы подереву. «MULTIDISZIPLINÄRE FORSCHUNG: PERSPEKTIVEN, PROBLEME UND MUSTER» 9. APRIL 2021 - WIEN, REPUBLIK ÖSTERREICH, DOI 10.36074/logos-09.04.2021.v2.44

12. Халимов Мохир Каримович, Жабборов Рустам Равшанович, Абдуханов БотирХусниддин угли, Мансуров Аскархужа Ахборхужа угли (2018). Сравнение продуктивности учебной доски и проектора в преподавании предметов, входящих в цикл инженерной графики. Молодой учёный, № 6 (192), 203205. 12.02.2018 г. https://moluch.ru/archive/192/48066/

13. Авазбаев А.И., Худайберганова М.Э.Формирование необычного или креативного мышления у учащихся в процессе обучения. Международный научный журнал «ВЕСТНИКНАУКИ» № 5 (26) Т. 3 МАЙ 2020 г.

14. Kozim Gafurovich Malikov. THEORY AND PRACTICE OF CONSTRUCTION OF AXONOMERTIC PROJECTS.European Journal of Research and Reflection in Educational Sciences Vol. 8 No. 9, 2020 ISSN 2056-5852. Progressive Academic Publishing, UK Page 224-231 www.idpublications.org

http://www.idpublications.org/ejrres-vol-8no-9-2020/

15. Jabbarov, R. (2019). Formation of Fine Art Skills by Teaching Students the Basics of Composition in Miniature Lessons. International Journal of Progressive Sciences and Technologies, 17(1), http://dx.doi.org/10.52155/ijpsat.v17.1.1424 pp-285-288.https://ijpsat.ijshtjournals.org/index.php/ijpsat/article/view/1 424

16. Nazirbekova, S. B., Talipov, N. N., \&Jabbarov, R. R. (2019). Described the Educational, Scientific, and Educational Institutions of the Miniature. https://ijpsat.ijsht-

journals.org/index.php/ijpsat/article/view/11 92

17. Valiev, A. (2021). ABOUT THE FEATURES OF THE PERSPECTIVE OF SIMPLE GEOMETRIC SHAPES AND PROBLEMS IN ITS TRAINING. Збірник науко вихпраць SCIENTIA. Вилученоіз

https://ojs.ukrlogos.in.ua/index.php/scienti a/article/view/10540

18. Жаббаров Рустам Равшанович (2019) Использование педагогического потенциала народных художественных промыслов как средства развития творческих способностей учащихся. INTERNATIONAL SCIENTIFIC PRACTICAL CONFERENCE "Improvement of the state 
The American Journal of Applied sciences (ISSN - 2689-0992)

Published: April 30, 2021 | Pages: 298-310

and non-state preschool education sectors: new forms and education content". pp-144146.

19. Жаббаров Рустам Равшанович (2016) Ўзликни англашнинг психологик асослари. The organization of innovative activities of the teachers: Problems and solutions. pp-444-445.

20. Saidaxbor BULATOV, Rustam JABBAROV. (2016) №2 National traditional basis of symbol of Khumo.Central Asian Journal of Education.Volume 1 , https://uzjournals.edu.uz/cjedu/pp-85-87.

21. Hasanov A.A., Gatiyatulina R.M. Interdisciplinary communication as a didactic conditions of increase of efficiency of educational process // Eastern European Scientific Journal Germany. Auris kommunikations-Und verlagsgesellschaftmdh 5-2016. P. 107-111.

22. Hasanov, A. A. (2020). PECULIARITIES OF PREPARING TEACHERS FOR THE DEVELOPMENT AND USE OF E-LEARNING RESOURCES. Theoretical \& Applied Science, (9), p.15-17.

23. Khasanov A.A. Didactic Foundations of Interdisciplinary Connections at Subject Teaching // Eastern European Scientific Journal. Germany -2018. No. 6. P. 127-130

24. Н.Н.Абдусаломходжаев. Исторические личности в творчестве малика Набиева. «MULTIDISZIPLINÄRE FORSCHUNG: PERSPEKTIVEN, PROBLEME UND MUSTER» 9. april 2021 - Wien, Republik Österreich. DOI:10.36074/logos-09.04.2021.v2.42

25. Djumaevich Khudoykulov Khol, Ergashevich Parmanov Aliboy, Ismailovich Avazbaev Atazhon, Juraevich Mirzaev Mutalib. The book of principle of human specialist. ACADEMICIA: An International Multidisciplinary Research Journal. 2020, Volume : 10, Issue : 7, ISSN : 2249-7137. Pp-
637-648 http://dx.doi.org/10.5958/2249-

7137.2020.00837.X 